\title{
Identifying the Needs of Youth in Establishing Social Interactions in the Context of Temporary Landscape of Mashhad City, Iran, Based on the Grounded Theory
}

\section{A R T I C L E I N F O}

\section{Article Type}

Original Research

\section{Authors}

Khorshidian E. ${ }^{1} M A$

Mohammadnia Gharaee $\mathrm{F}^{* 1} P h D$,

Ostadi M. ${ }^{1} P h D$

\section{How to cite this article} Khorshidian E, Mohammadnia Gharaee F, Ostadi M. Identifying the Needs of Youth in Establishing Social Interactions in the Context of Temporary Landscape of Mashhad City, Iran, Based on the Grounded Theory. Geographical Researches Quarterly Journal. 2019 34(2):165-174.
${ }^{1}$ Department of Urbanism, Faculty of Art \& Architecture, Mashhad Branch, Islamic Azad University, Mashhad, Iran

\section{*Correspondence}

Address: Emamiye Boulevard, Ostad Usefi Avenue, Islamic Azad University, Mashhad, Iran

Phone: +98 (51) 37136793

Fax: -

gharaee.fatemeh@gmail.com

\section{Article History}

Received: July 17, 2018

Accepted: February 03, 2019

ePublished: June 20, 2019

\section{A B S T R A C T}

Aims \& Backgrounds With the development of technology, time has become more limited to the presence in urban spaces and the experience of spaces and visual relations. In this regard, in the process of fitting the urban environment, it is necessary to create spaces not only in accordance with the needs of today, but also the qualities beyond the obvious qualities of space. In these spaces, we must try to create close communication and encouraging people to more presence in communal spaces. The aim of this research was to identify the needs of youth in establishing social interactions in the context of temporary landscape of Mashhad city, Iran, based on the grounded theory.

Methodology This qualitative research was carried out on the youth community of Mashhad city in the age range of 20-30 in 2017. The interviews were conducted on the Janbaz, Sajjad, Koohsangi, and Ahmad-Abad streets of Mashhad city. The views of the interviewees followed theoretical saturation from the 44th interview.

Findings After the initial stages, coding of sentences and clauses was performed and they categorized in 3 levels of casual, basic, and intermediate conditions.

Conclusion The Willingness to participate, right to choose, freedom of action, presence in the happy urban spaces, feeling of belonging and attachment, preservation of indigenous traditions are identified as the needs of youth in establishing social interactions.

Keywords Youth; Social interactions; Temporary landscape; Grounded Theory

\section{T A T I O N L I N KS}

[Hang; 2007] A temporary landscape recipe-to reclaim Hong Kong's lost landscape opportunity [Dissertation]; [Askari Nadoushan \& Sabaghchi 2018] The Use of Importance-Performance Analysis (IPA) in evaluating gap between youth needs and policies' proprieties in Yazd; [Cheshmeh Ghesabani \& Karimi; 2011] An analytical approach toward cultural events effects on temporary urbanscape; [Correy; 1978] Ephemeral landscape, A case for temporary landscape design in a changing society: Utopian technology fair; [Darbandi; 2007] A new chance for thinking; [Elyasi, et al; 2017] Reconstruction of urban gardens with emphasis on community development (Case study: Mahabad gardens); [Mayo; 2009] Temporary landscape; [Miles; 2014] Youth Sociology; [Ghalambar \& Naghizade; 2014] Urban space design to promote social interactions (Case study: Inter-district Blvd); [Mohammadi \& Sharepour; 2018] Investigation of the youth's social relationships and their interactions in park (Case study: Amol city); [Qhanbaran \& Jafari;2015] Investigating the factors affecting the promotion of social interactions among residents of the residential neighborhood (Case study: Dereh-e-Tehran); [Rogers; 2006] Young People's participation in the renaissance of public space- a case study in Newcastle Upon Tyne, UK; [Shojaei \& Partoee; 2015] Analysis of factors affecting the creation and promotion of sociability in public spaces in different scales of Tehran city (Case studies: Two neighborhoods and an area in district 7 Tehran); [Siami, et al; 2013] Locating the temporary landscapes in order to improve the quality of the urban living environment; [Tusi Sadr; 2013] The life of young people in the city; [White;1998] Public space for young people: A guide to creative projects and positive strategies 
اين فضاها غالباً به نياز انسان بهعنوان يك موجود اجتماعى

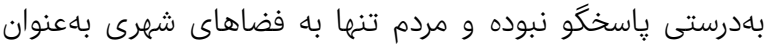

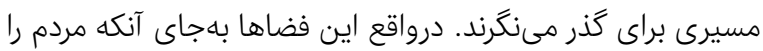

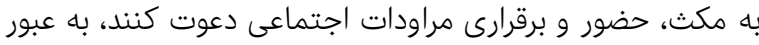

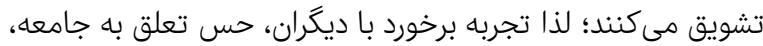
ديدارهاى جهره به جهره، تعاملات اجتماعى بهدرستى اتفاق نمى لئافتد

[Shojaee \& Partoee, 2015] از اينرو امروزه انسان نيازمند فضاهايى است كه علاوه بر إن كيفيتهاى عام محيط كيفيتهايى فراتر از آن را ارايه كند؛ با اين آنان

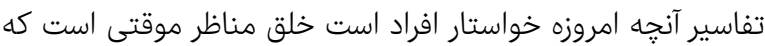

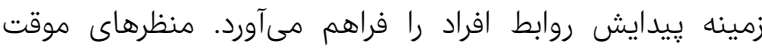

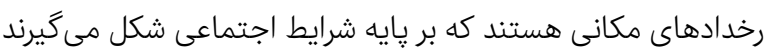

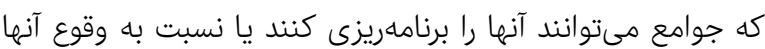

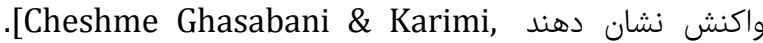
[2011 تنها ضرورت اين مكانها معمولاً فضايى گسترده است كه

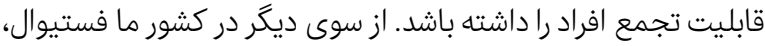

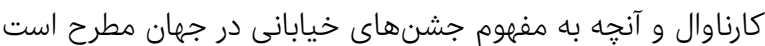

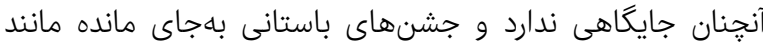

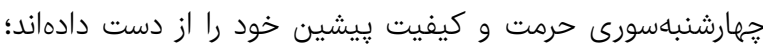

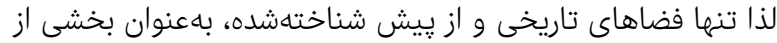

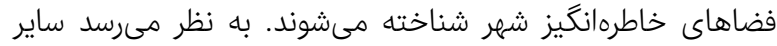

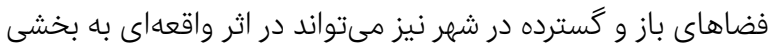
از سرمايههاى فرهنكى و اجتماعى شهر و مردم بدل شود Siyam .et al, 2014] از سويى برنامهريزان بهعنوان كروهى كه با آكاهى به نيازهاى جامعه

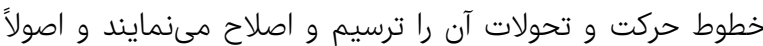

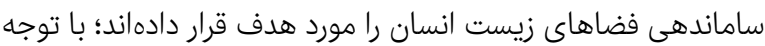

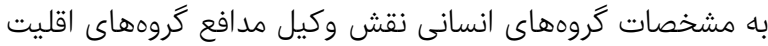

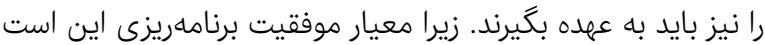

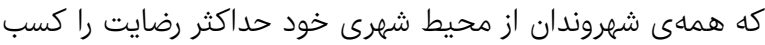

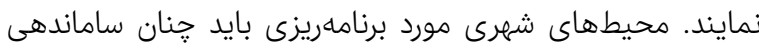

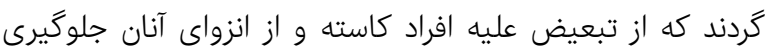

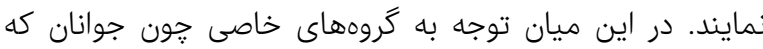

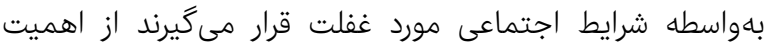

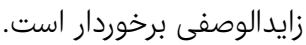

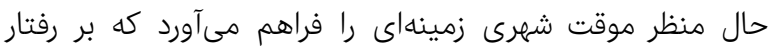

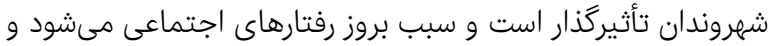

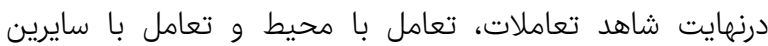

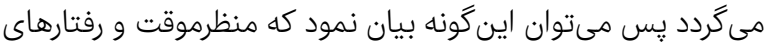

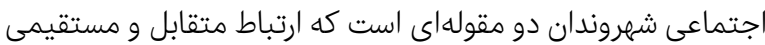

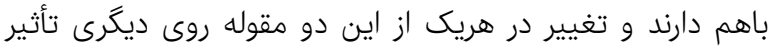

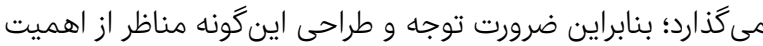

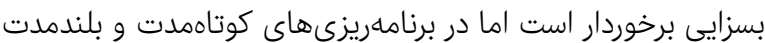

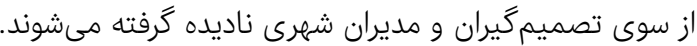

شناسايى نيازهاى جوانان در برقرارى تعاملات اجتماعى در بستر مناظر موقت شهر مشهد مبتنى

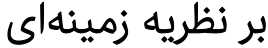

MA الناز خورشيديان كروه شهرسازى، دانشكده هنر و معمارى، واحد مشهيد، دانشكاه آزاد اسلامى، مشهد، ايران

فاطمه محمدنياى قرائى PhD كروه شهرسازى، دانشكده هنر و معمارى، واحد مشهد، دانشكاه آزاد اسلامى، مشهد، ايران

PhD مريم استادى ايران كروه شهرسازى، دانشكده هنر و معمارى، واحد مشهد، دانشگاه آزاد اسلامى، مشهد، ايران

جكيده اهداف و زمينهها: با توسعه تكنولوزى زمان حضور در اكثر فضاهاى شهرى و

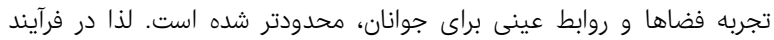

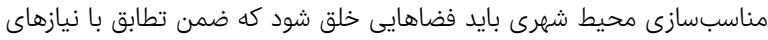

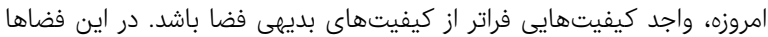

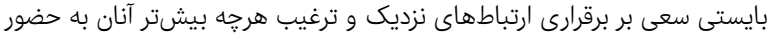

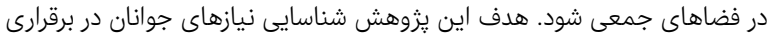

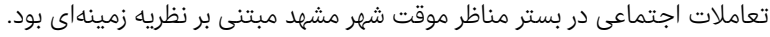

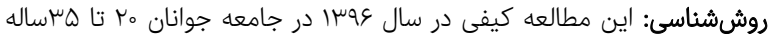

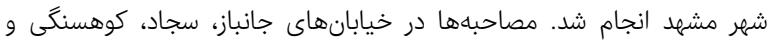

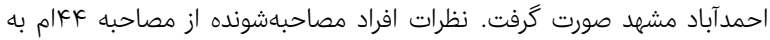

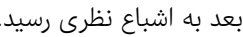

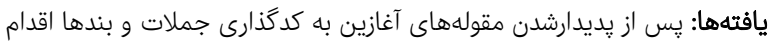

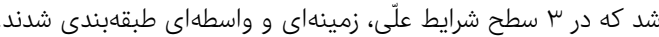

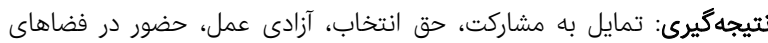

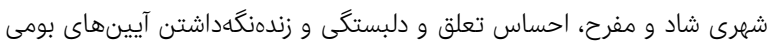

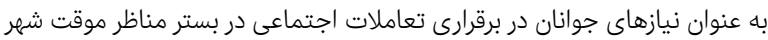
تشخيص داده شد. كليدواثهها: جوانان، تعاملات اجتماعى، منظرموقت، نظريه زمينهاى

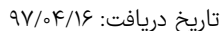

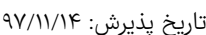
نويسنده مسئول: gharaee.fatemeh@gmail.com تاريخ:

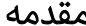

توليد و بازتوليد فضاهاى عمومى بهعنوان محل رخداد تعاملات

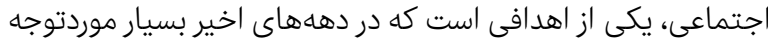

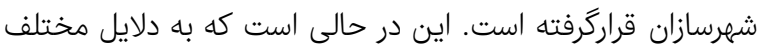

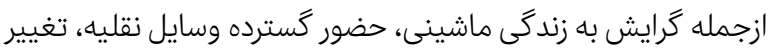

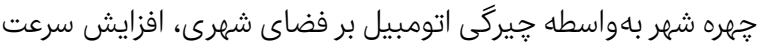

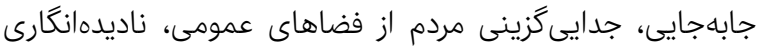

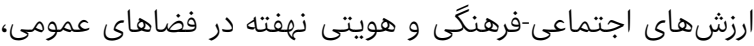

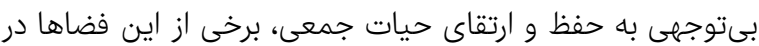
مقياسهاى مختلف شهرى اهميت و نقش خود را ازدست بردادادهاند. 
شناسايى نيازهاى جوانان در برقرارى تعاملات اجتماعى در بستر مناظر موقت شهر مشهد مبتنى بر نظريه زمينهاى

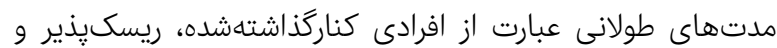

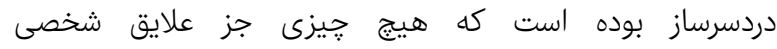
طغيانكرانهشان آنها را تحريك نمى دردند. در مقابل واقعيات هر هر روزه

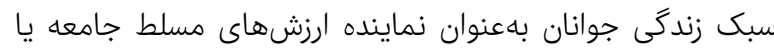

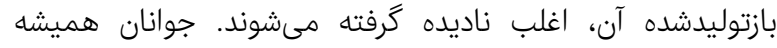

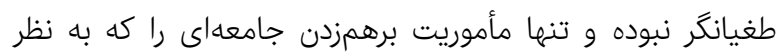

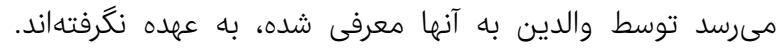

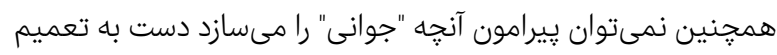

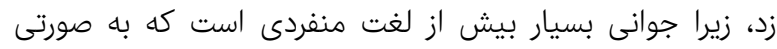

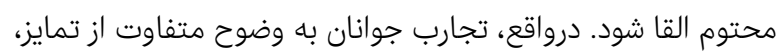
تنها براساس متغيرهايى نظير طبقه، جنسيت و تحصيلات است

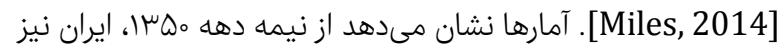

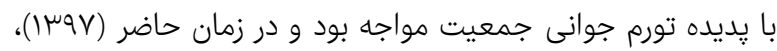

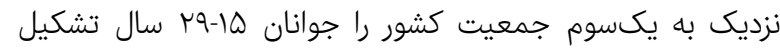

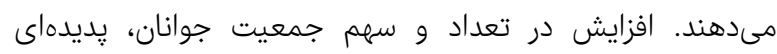

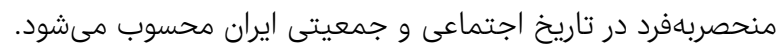

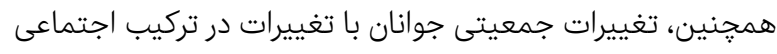

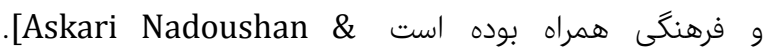

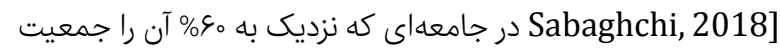
زير مس سال تشكيل مىدهند و بهعنوان جمعيت جوان شناخته

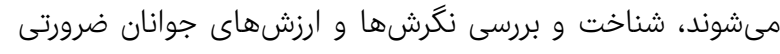

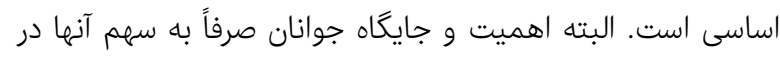

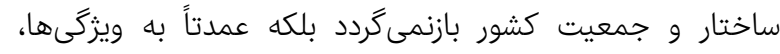

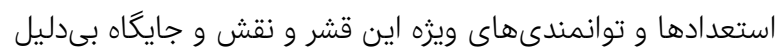
آنها در تحقق اهداف توسعه مربوط مىشود [Darbandi, 2007] جوانان از مهمترين قشر هر جامعه محسوب مى دُوند و حضور فعال

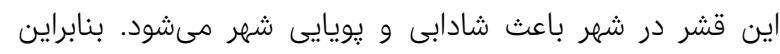

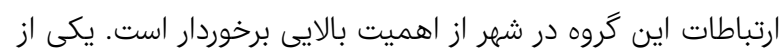

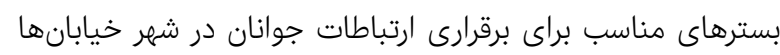

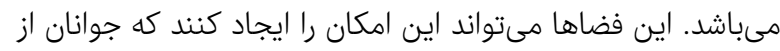

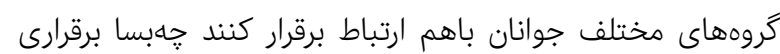

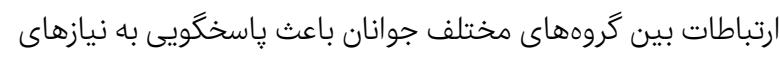

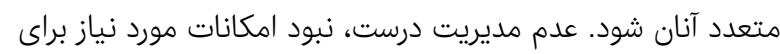

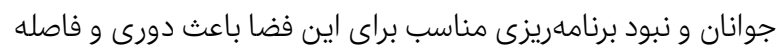

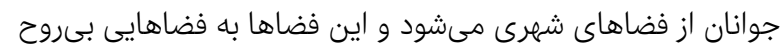

تبديل مىشود [Mohammadi \& Sharepour, 2018] در واقع جوانان در روابط اجتماعى با ديكران به دنبال ارضاى

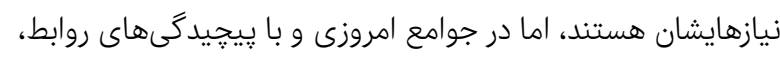

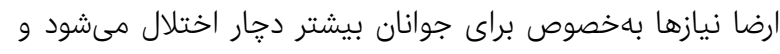

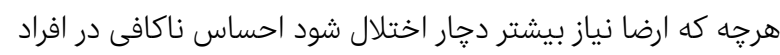
مربوط و اعضاى جامعه بيشتر مىشود و به همين ميزان احتمال

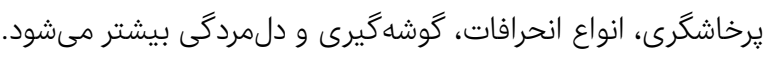

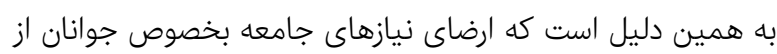
اهميت ويزهاى برخوردار است [Rafipour, 2001].
فضاهاى شهرى بخشى از فضاهاى باز و عمومى محسوب مىشوند

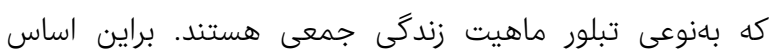
فضاهاى شهرى عرصه تعامل متقابل انسانها هستند كه داستان

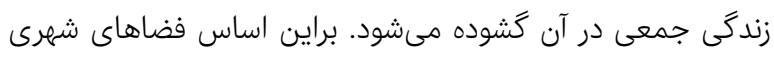

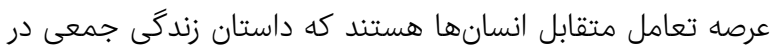

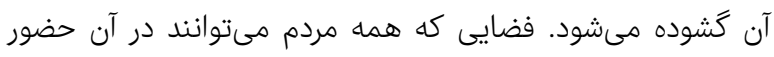

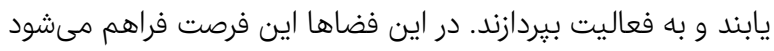

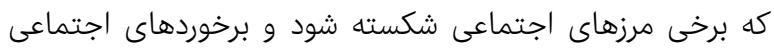
صورت كيرد [Ghalambar Dezfoli \& Naghizade, 2014]. درنتيجه افراد براساس منافع خود، ارتباطات اجتماعى را شكل داده و

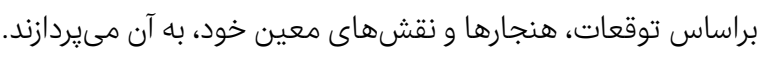

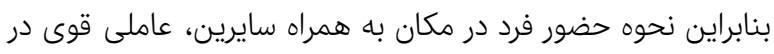

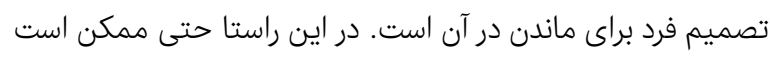

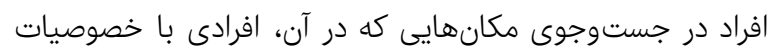

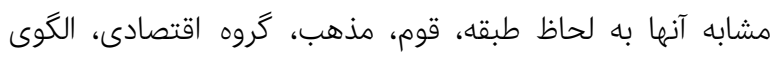
زندگى، تحصيلات، درآمد، نحوه تربيت كودكان و نزاد مشابه حضور

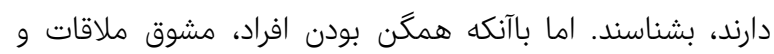

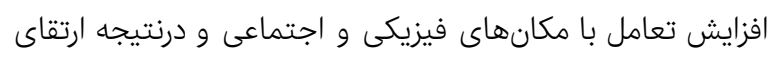

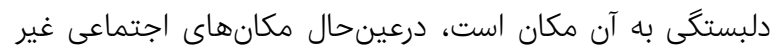

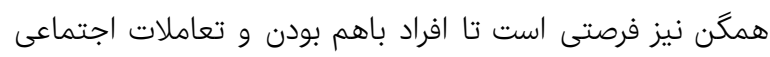

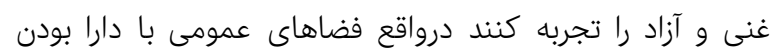
ظرفيتهاى بالقوه در مرحله نخست اين فرصت برابر را جهت ائن ايجاد

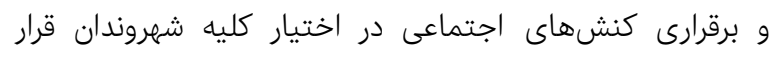

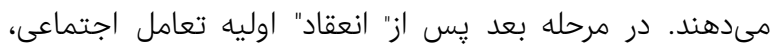

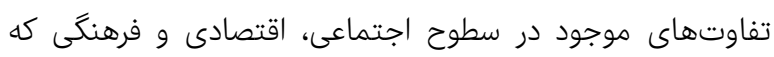

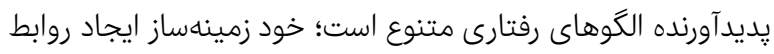
[Qhanbaran \& Jafari, اجتماعى منسجم و پايدار خواهند شئل [2014 از طرفى وجود فضاهاى جمعى نقش بسيار مهمى در جذب آنس

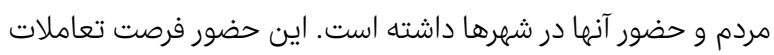

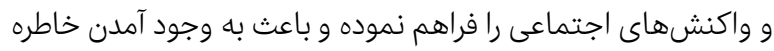
جمعى مشترك و حس تعلق به فضا مى گردد. فضاى جمعى بهاءز

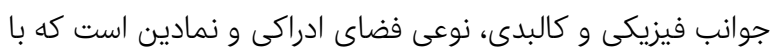

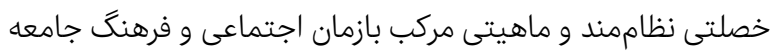

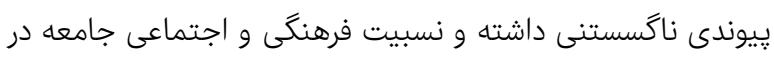

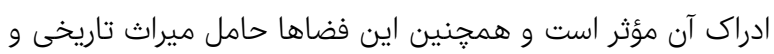

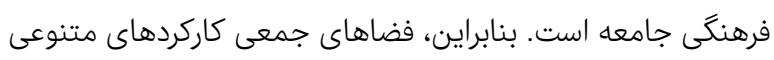

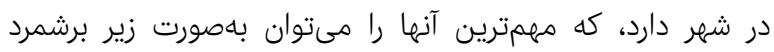

:[Elyasi \& Zandiye, 2017]

محلى براى گردهمايى و اجتماع شهروندان؛ تقويت نقش اجتماعى شهروندان در مسير دستيابى به توسعاه ورايدار؛

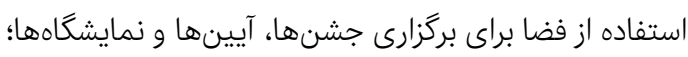

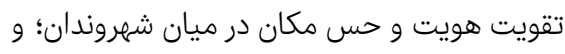

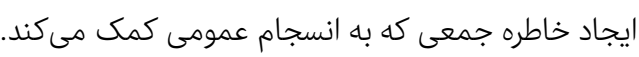
تصويرى كه دانشمندان علوم اجتماعى از جوانان ترسيم كردهاند براى لهاى 
קكونكى ترغيب جوانان بيشتر در مشاركت داوطلبانه در مجامع مربوط به آنها. קُكونكى به دست آوردن بهترين اطلاعات، توصيهها و راهنمايىها

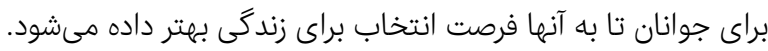

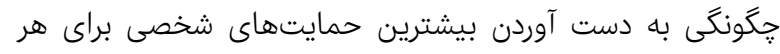

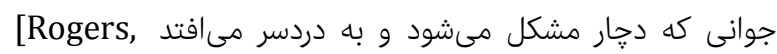

.2006]

معنى واقعى موقت קيست؟ اين اصطلاح ابعاد گَوناگونى دارد كه

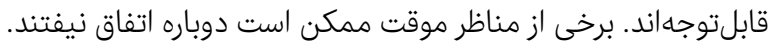

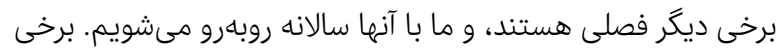

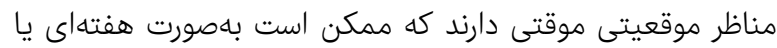

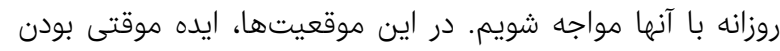

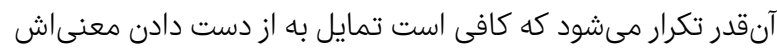

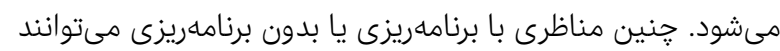

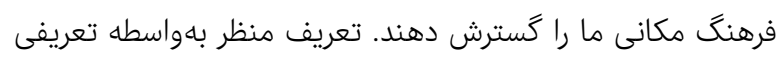

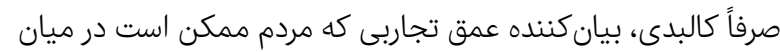

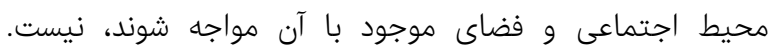

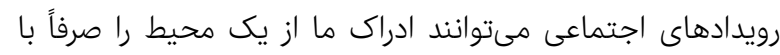

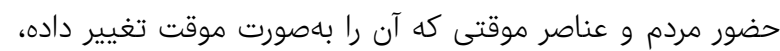

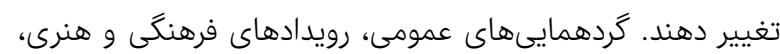

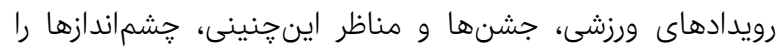

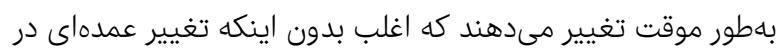
كيفيت طبيعى و كالبد دايمى منظر ايجاد كنند مكانى را براى دراى

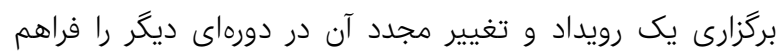

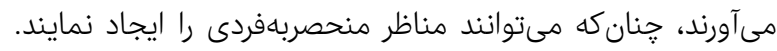

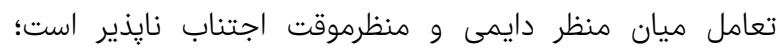

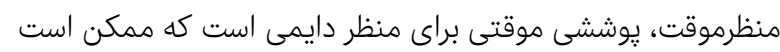

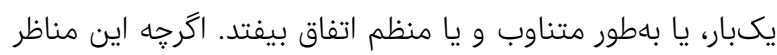

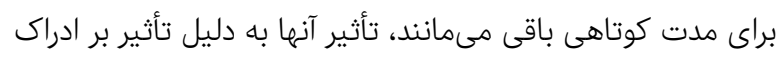

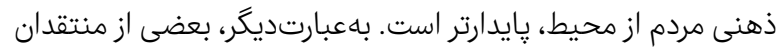

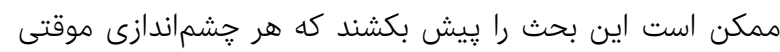

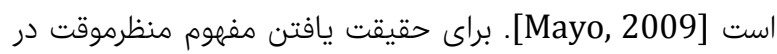

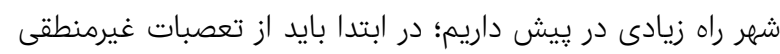

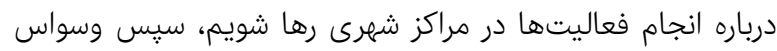

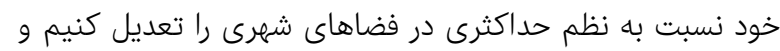

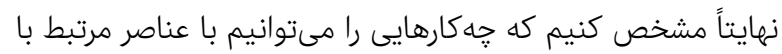

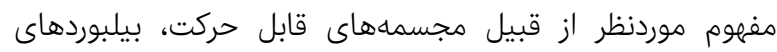

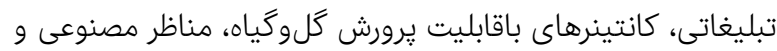
يا سطوح مصنوعى يرورش گياه و ساير موارد مشابه انجام دام دهيم.

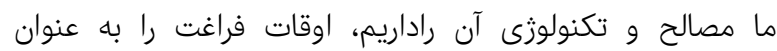

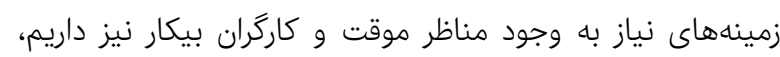

همهجيزى كه ما نياز داريم انكيزه است [Correy, 1978.

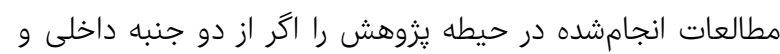

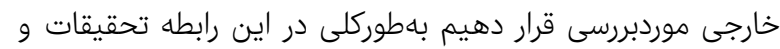

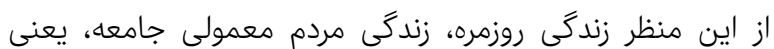

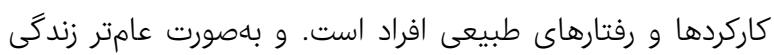

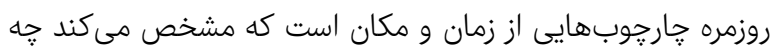
كارى، جه وقت، كجا و با קه كسى انجام شود و و شكستن انتظارهاى

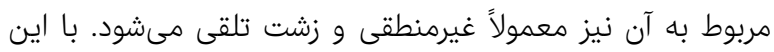

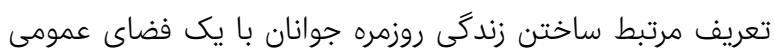

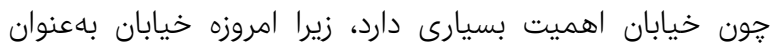

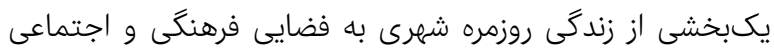

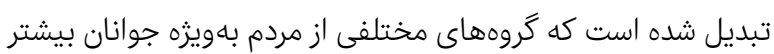

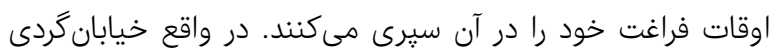

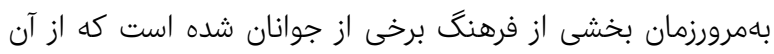

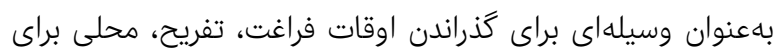

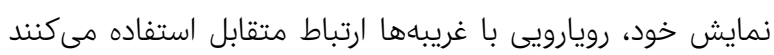

[TousiSadr, 2013]

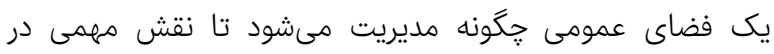

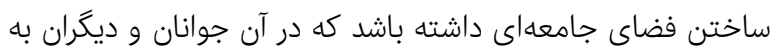

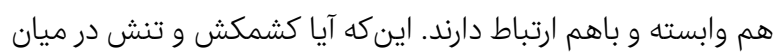

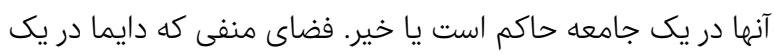

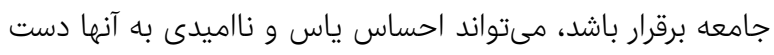

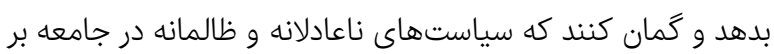

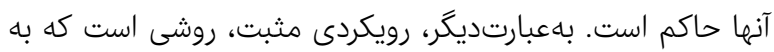

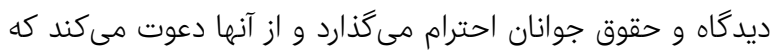

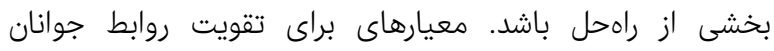
قابلتشخيص است كه شامل زير است:

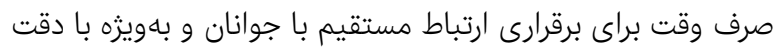

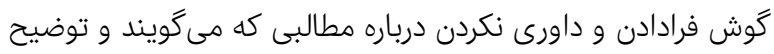
دادن قوانين و اصول رفتارى كه در مكانهاى خاص دارئ لازم است رعايت كنند.

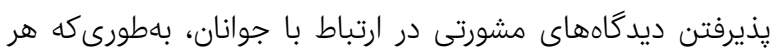

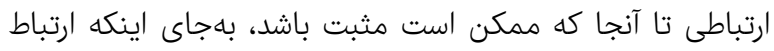

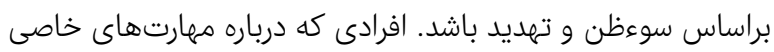

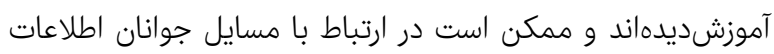

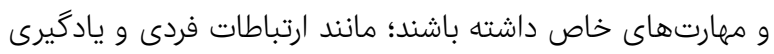
در مورد فنهاى گَوناكون حل اختلاف. تمايل به "ديده شدن" در نظرسنجىهاى مناى منظم محلى به شكايات جوانان به منظور كارايى بهتر. با انصاف و احترام با جوانان رفتار كردن در مورد حقوق شهروندى

[White, 1998]

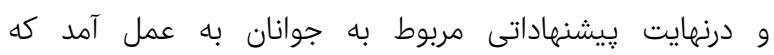

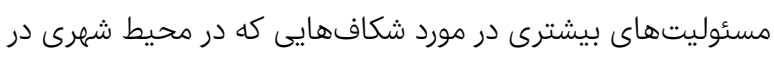

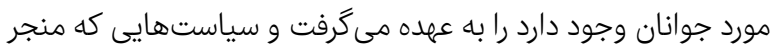
به بهترين عملكرد بود اعمال شد:

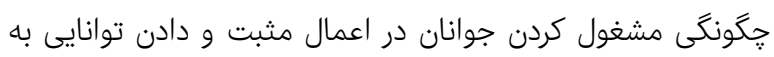
آنها در شكل دادن به خدماتى كه دريافت مىكنئن 
شاضن

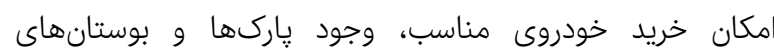

مخصوص بانوان و غيره را در الويت نيازهاى جوانان قرار مىدهند. بررسى محيطهاى عمومى شهرى با توجه به نيازهاى جوانان و و

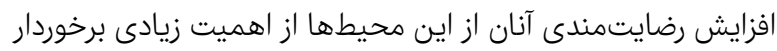

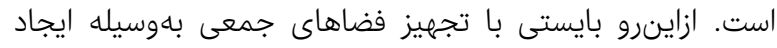

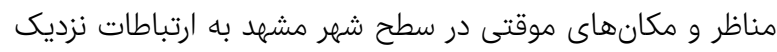

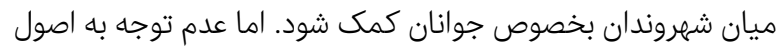

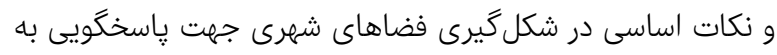
اين فعاليتها و فقر فضايى و مكانى در حمايت ايجاد مناظر موقت

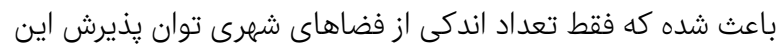

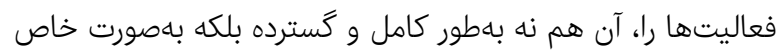

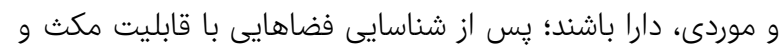

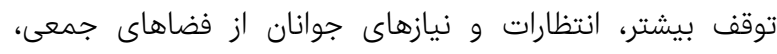
بهخصوص فضاهاى موقتى مورد بررسى قرار گرفت تا فضاهاى

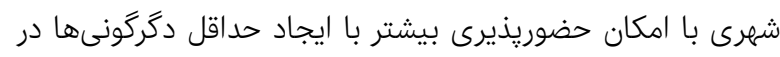

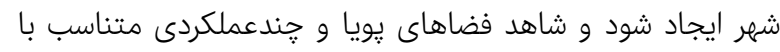

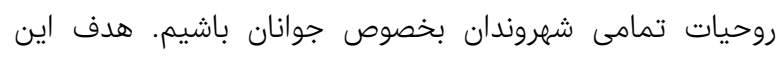

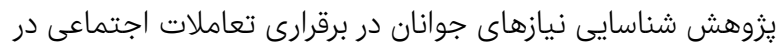
بستر مناظر موقت شهر مشهد مبتنى بر نظريه زمينهاى بوائ بود.

\section{روش}

اين مطالعه كيفى در سال عوسا در جامعه جوانان مr تا هسالهى مشاله

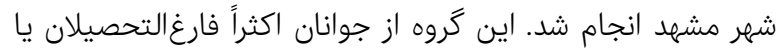

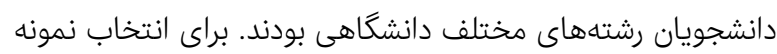

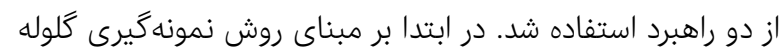

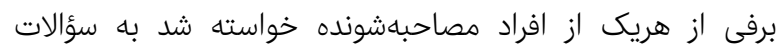

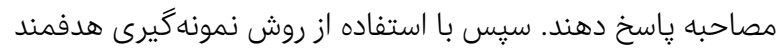
آن دسته از جوانان كه در حيطه خاص دعمارئ سيس بارى و شهرسازى تحصيل

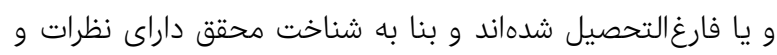

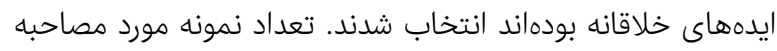
براساس اصل اشباع در حجم نمونه در نظر گرفته شد. مصاحبه ها در

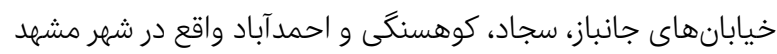

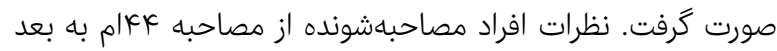

به اشباع نظرى رسيد.

ابزار گردآورى اطلاعات در اين يزوهش رسيد مصاحبه بود. براى اين منظور

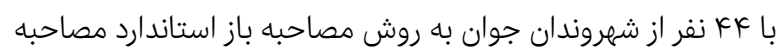
شد. در ابتداى هر مصاحبه نيز با ارايه توضيحات مفصل ابهامات

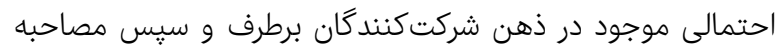

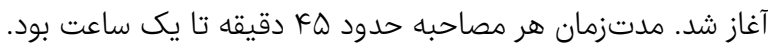

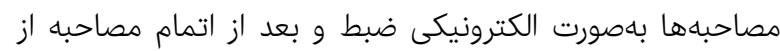

روى فايل صوتى، مفاهيم استخراج شد.

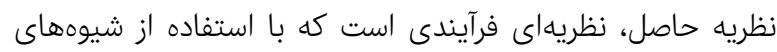

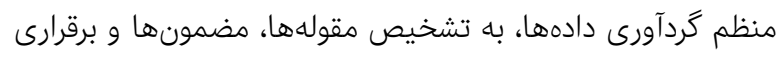

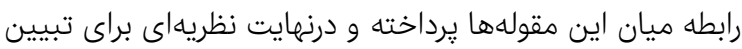

يزوهشهاى زيادى صورت نكرفته است. يزوهش حاضر از دو كليدوازه جوان و منظر موقت تشكيلشده كه بهصورت مجزا در ذيل به سوابق هركدام اشاره شدهاست. آلنكرى [Correy Allan, 1978] در مقاله خود تحت عنوكان سندان

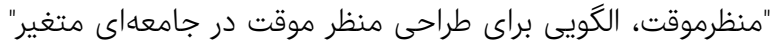

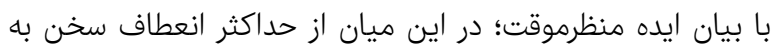

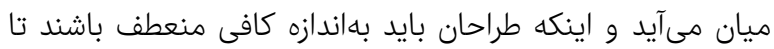

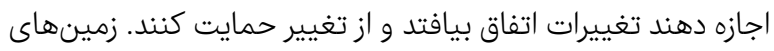

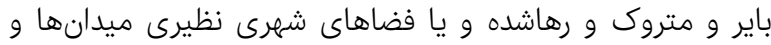
تفرجًاهها را باه عنوان بسترى براى انجام ايده منظر موقت مطرح

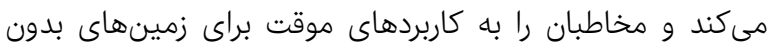

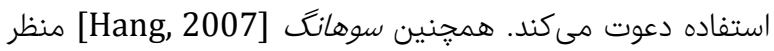

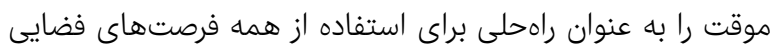
و بهكارگيرى همه توان بالقوه زمينهاى تحت استى برى استفاده و رهاشده

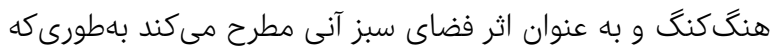

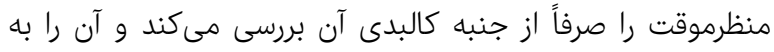

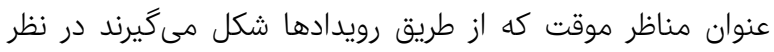

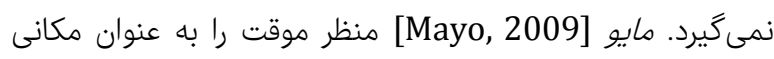

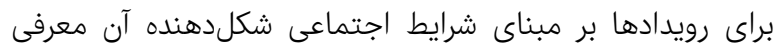

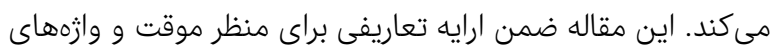

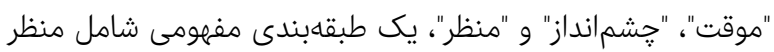

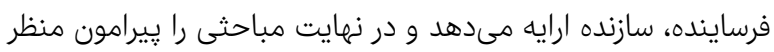

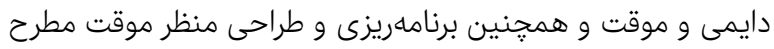

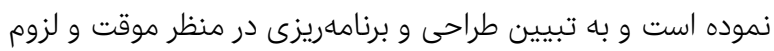

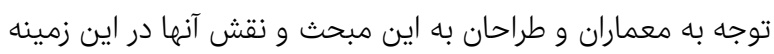

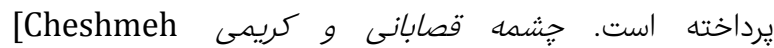
مناظر موقت شهرى را بسترى Ghesabani \& Karimi, 2011] براى تعامل انسان با محيط و انسان با انسان مىدانند كه اين تعامل

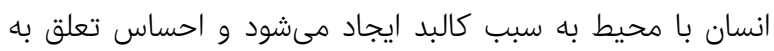

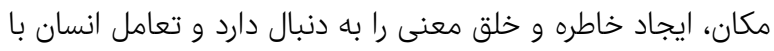

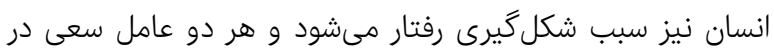
ايجاد هويت دارند. صيامى و همكاران [Siami et al, 2013] معتقدند معيارهايى جون كاربرى و دسترسى، مهمترين نقش را در در مكانيابى مناظر

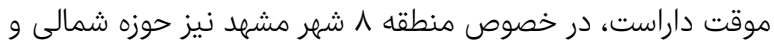

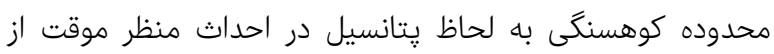
موقعيت خوبى برخوردار است. راب وايت [White, 1998] سعى دارد با احترام و رعايت حقوق،

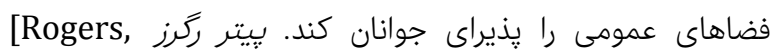

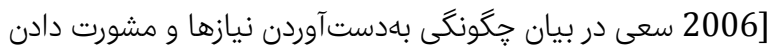
جوانان در بازسازى شهرى دارد. [Askari Nadoushan \& عسكرى ندوشن و همكاران

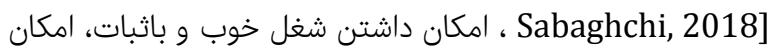
كسب درآمد، توانايى تأمين مخارج زندگى، وجود يارك و تفريحكاه، 
به يديدهاى دلالت مى كند؛ بهاعبارتديكر زمينه عبارت است زئه از سلسله

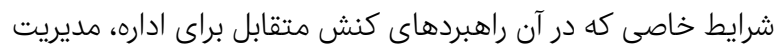

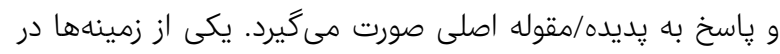

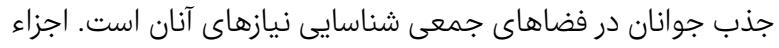

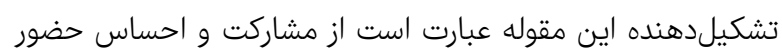

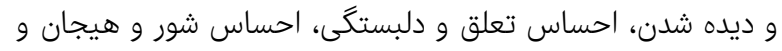

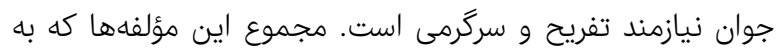

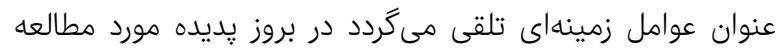
نقش اساسى دارد. بهطورىكه حضور در فضاهاى جمعى كمك به به مينه

برقرارى روابط نزديك ميان جوانان دارد.

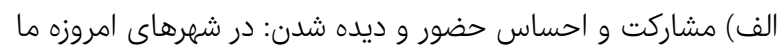

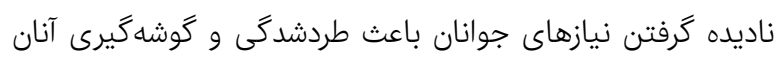

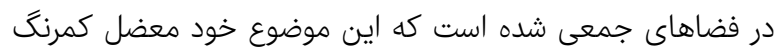

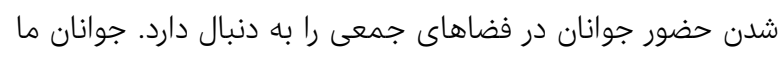

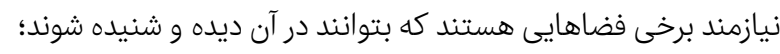

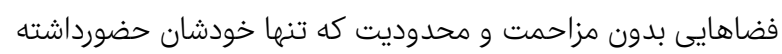
باشند. همجنين وقتى به جوانان بهاداده شود حس مشاركت درو در آنها

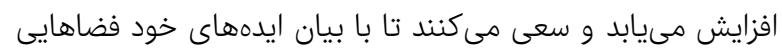

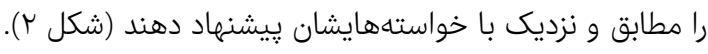

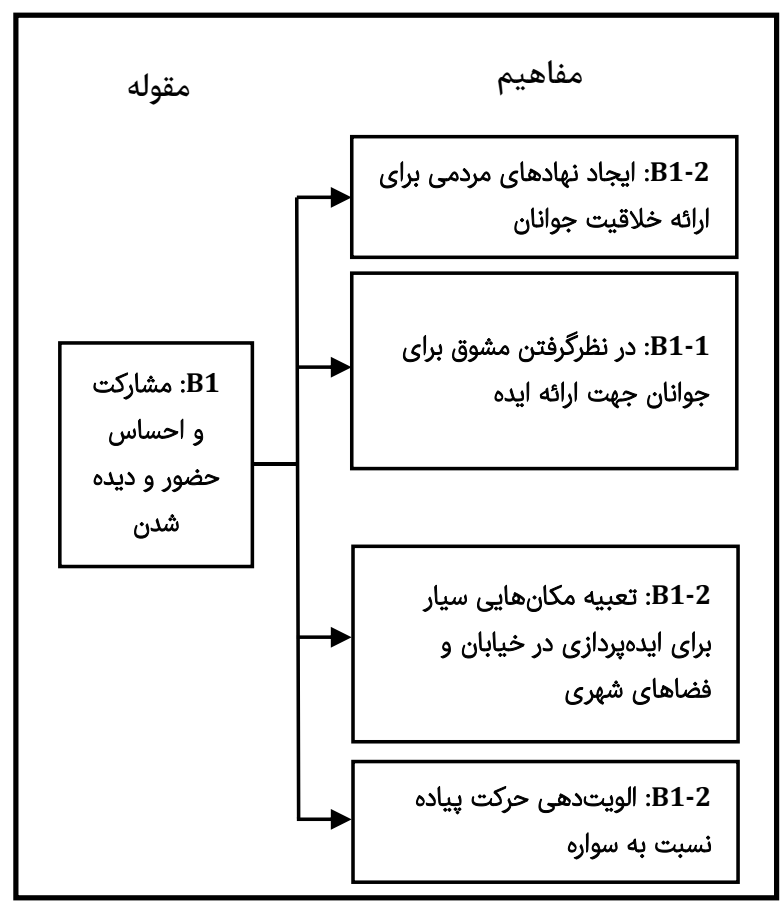

شكل r) شرايط زمينهاى؛ مشاركت و احساس حضور و ديده شدن جوانان در شهر

ب) احساس تعلق و دلبستگى: متأسفانه جوانان ما خاطرات جمعى

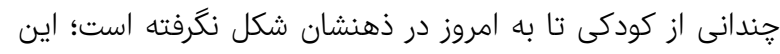

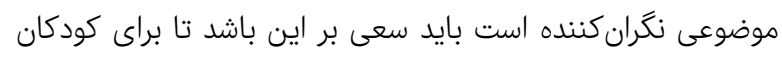

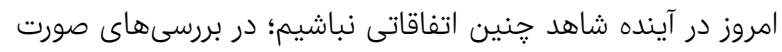

شكل () شرايط على؛ احساس رضايتمندى از فضاهاى جمعى و كشف مكانهاى

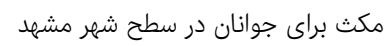


IVI شناسايى نيازهاى جوانان در برقرارى تعاملات اجتماعى در بستر مناظر موقت شهر مشهد مبتنى بر نظريه زمينهاى

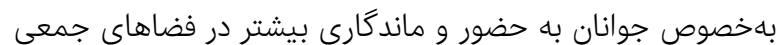

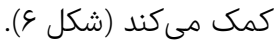

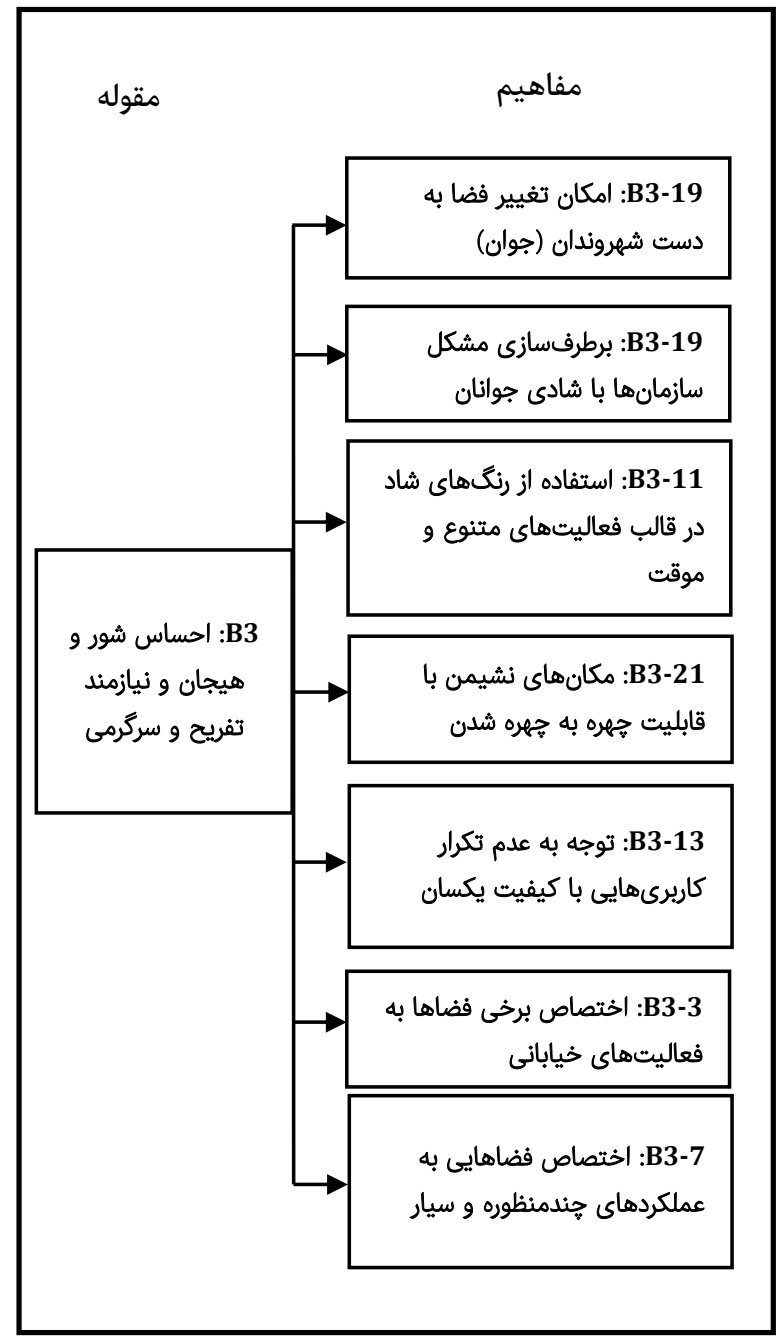

شكل F) شرايط زمينهاي؛ احساس شور و هيجان و نيازمند تفريح و سركرمى در شهر مشهد

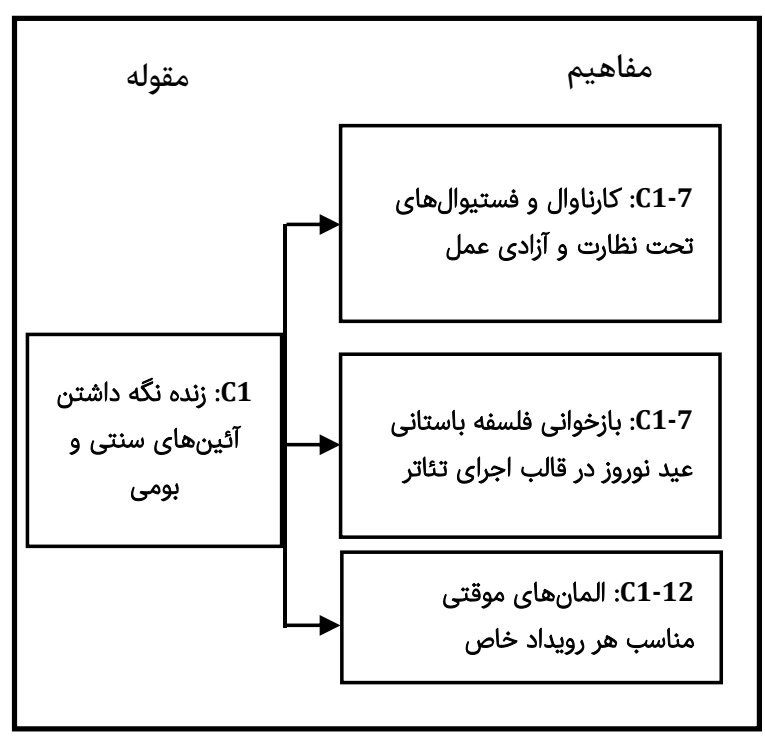

شكل ه) شرايط واسطهاى؛ زنده نكًه داشتن آيينهاى سنتى و بومى شهر مشهد
گرفته جوانان اظهار داشتند با در نظر گرفتن المانهاى نوستالزيك و يا فضاهاى جمعى متنوع مىتوان هر رويدادى از سال را جهت

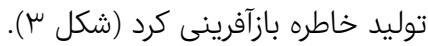

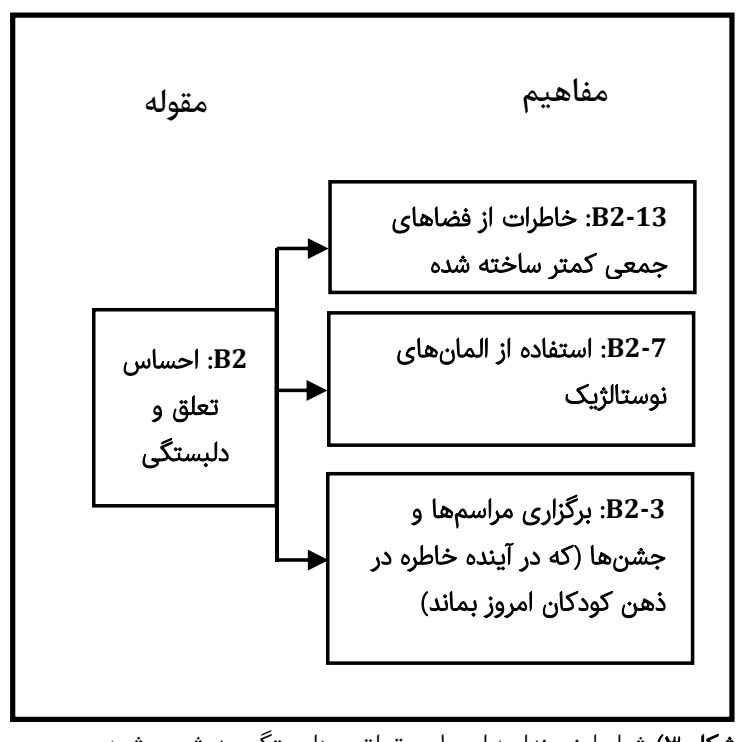

شكل س) شرايط زمينهاى؛ احساس تعلق و دلبستگى به شهر مشهد

ج) احساس شور و هيجان و نيازمند تفريح و سركرمى: امروزه با

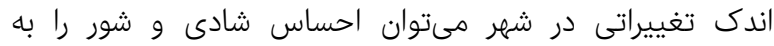

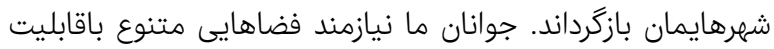

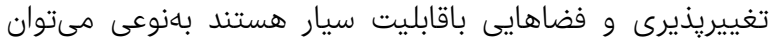

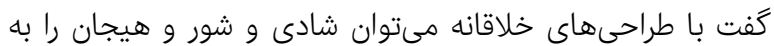

شعرهاى امروزمان بازكردانيم (شكل F (F).

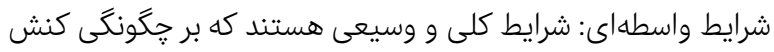

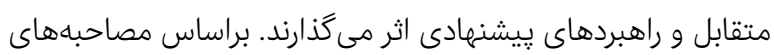
انجامشده و تحليل آنها شرايط واسطهاى موردنظر در اين تحقيقايق

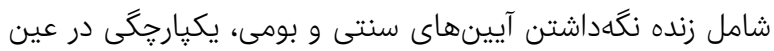

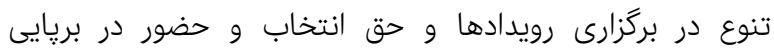

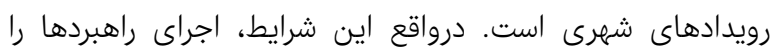

تسهيل و تسريع كرده و يا به عنوان مانع دهار تأخير مى كندا.

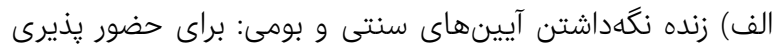

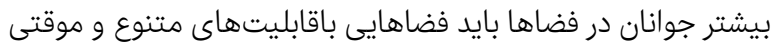

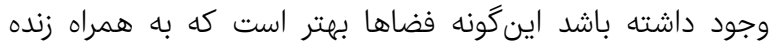

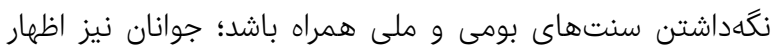

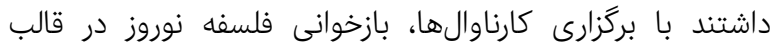

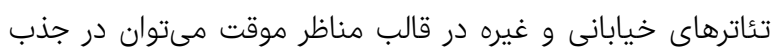

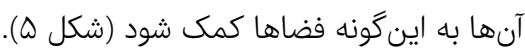

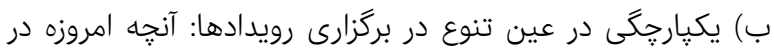

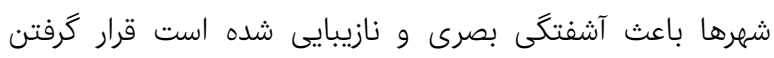

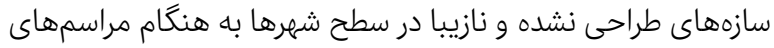

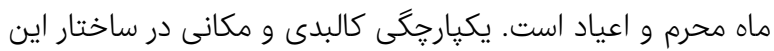

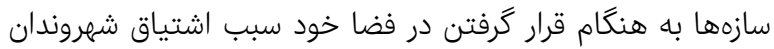


جهاركانهاى بيشنهاد مىشود اين راهبردها عبارتاند از:

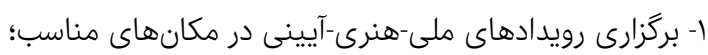

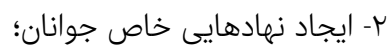

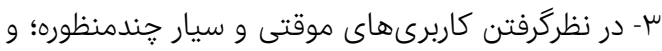

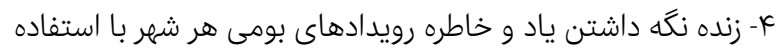
از عناصر نوستالزيك به صورت موقتى.

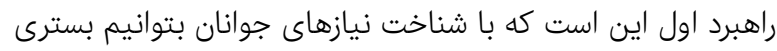

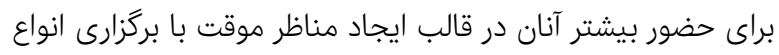

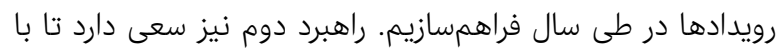

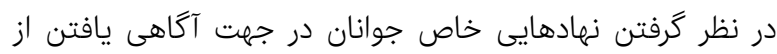

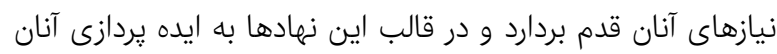

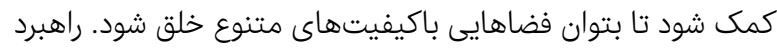

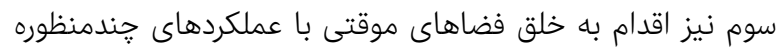

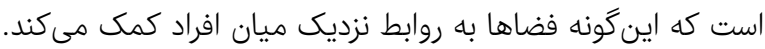

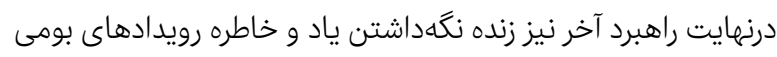
و سنتى هر شهر از طريق المانها و عناصر نوستالزيك است. يُّيامدها:

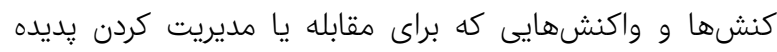

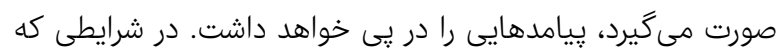

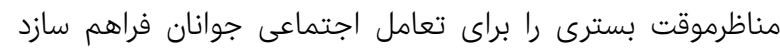

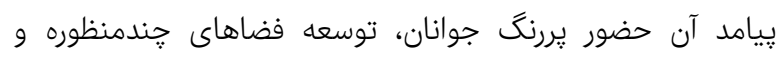
شكل گيرى سبك جديدى از فضا در قالب مناظر موقت شهرى است.

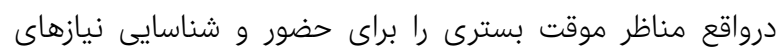
جوانان فراهم مىسازد.

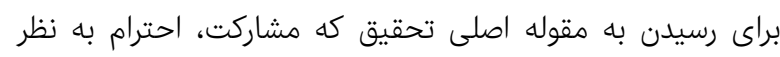

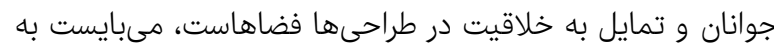
نيازهاى جوانان توجه داشت. تحليل محتواى نيان نيازها و وانتظارات دات دان

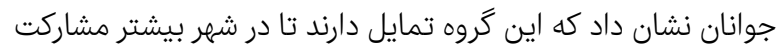

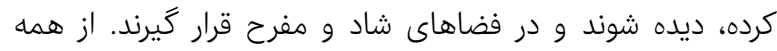

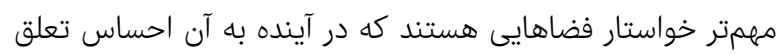

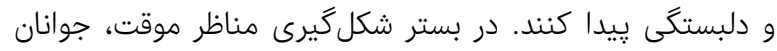

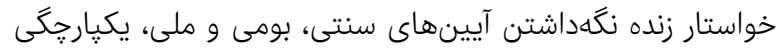

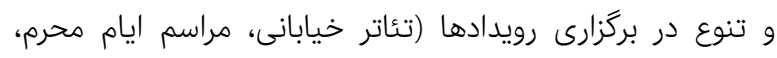

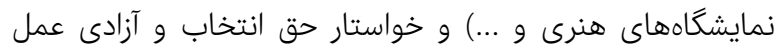

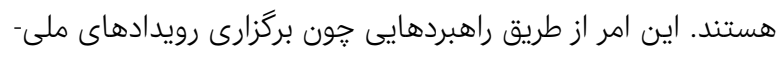

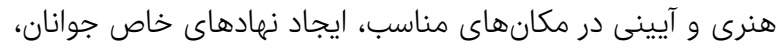

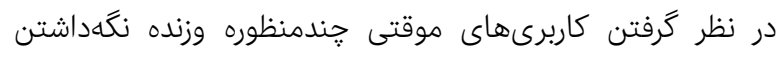

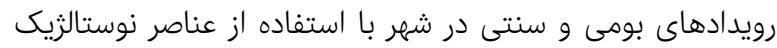

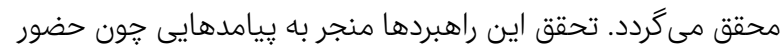

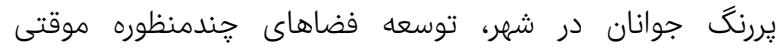

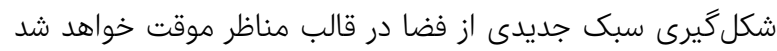

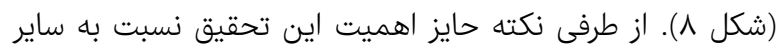

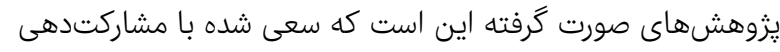

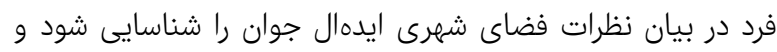
صرفاً به بيان نظرى و نظرات كارشناسانه بسنده نشود.

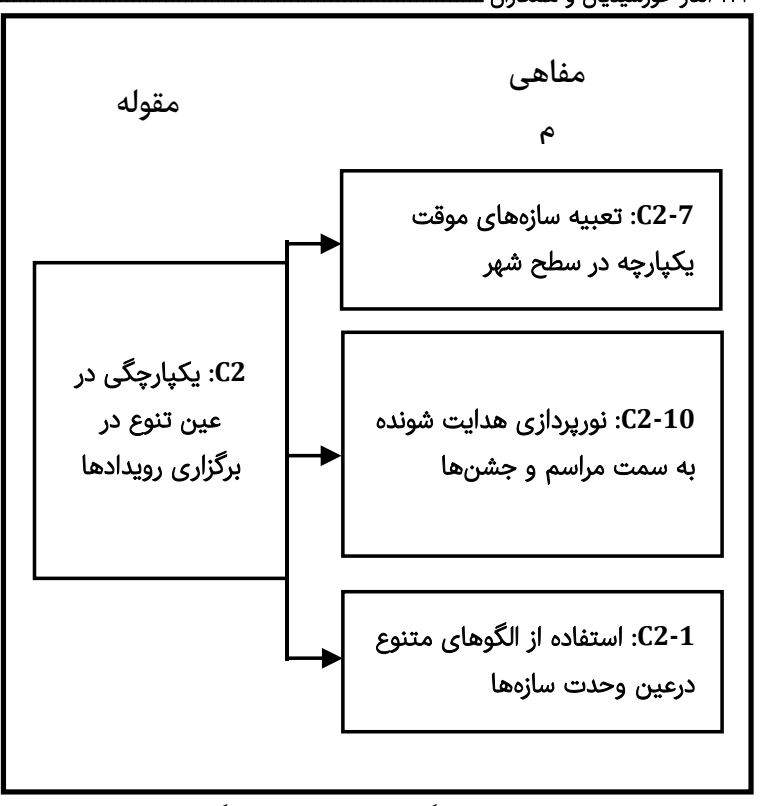

شكل ع) شرايط واسطهاى؛ يكيارجكى در عين تنوع در بركزارى رويدادها در سطح شهر مشهد

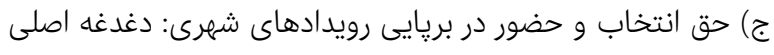

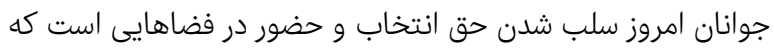

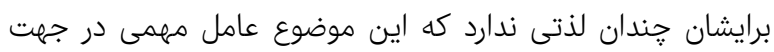

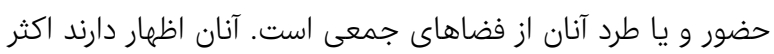

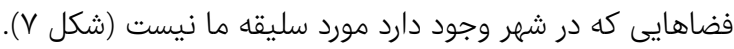

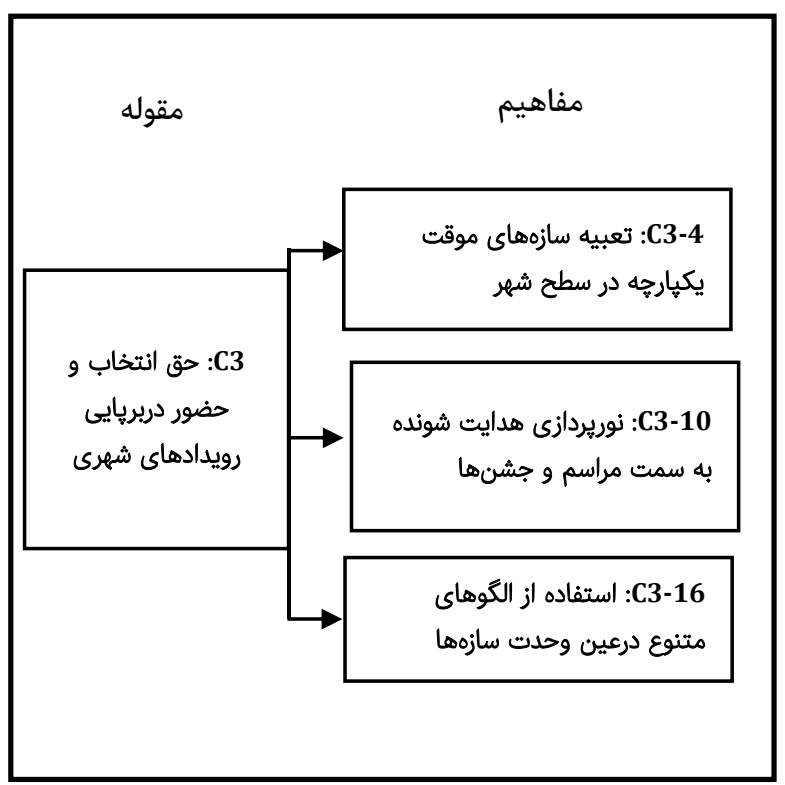

شكل V) شرايط واسطهاى؛ حق انتخاب و حضور در بريايى رويدادهاى شهرى در شهر مشهد

\section{بحث}

راهبردها و اقدامات، طرحها و كنشهايى هستند كه كمك به ايجاد

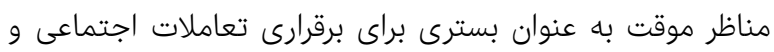

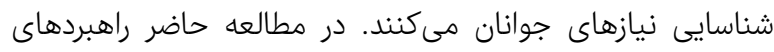




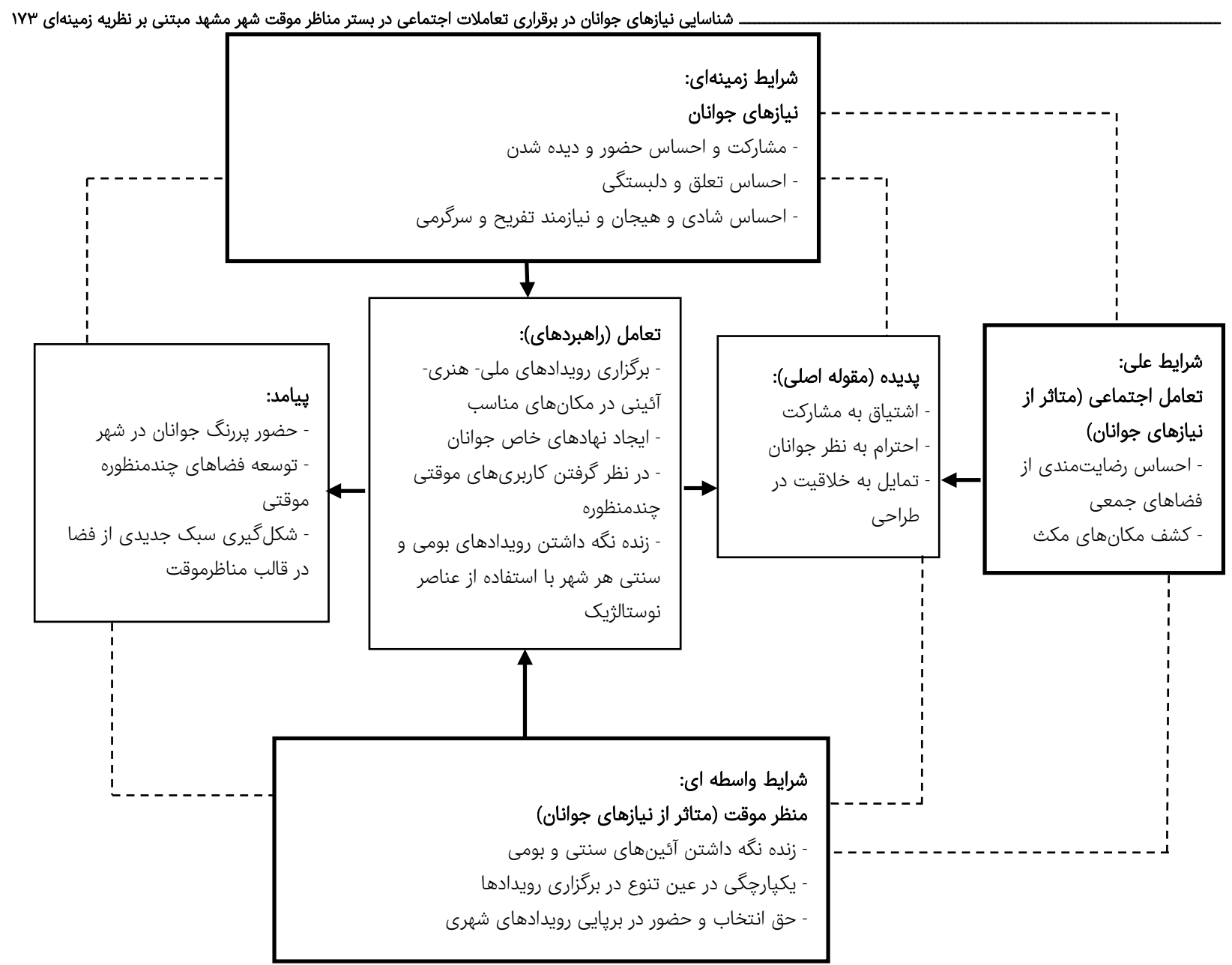

شكل A) مدل نهايى؛ شناسايى نياز جوانان با بهركگيرى از منظر موقت شهرى

Cheshmeh Ghesabani M, Karimi N (2011). An analytical approach toward cultural events effects on temporary urbanscape. Hoviatshahr. 5(9):27-36. [Persian]

Correy A (1978). Ephemeral landscape, A case for temporary landscape design in a changing society: Utopian technology fair. Sydney: University of Sydney. Darbandi AR (2007). A new chance for thinking. Youth Studies. 8-9:4-6. [Persian]

Elyasi E, Zandiye M, Mahmodi A (2017). Reconstruction of urban gardens with emphasis on community development (Case study: Mahabad gardens). Journal of City Landscape Research. 3(6):25-42. [Persian]

Mayo JM (2009). Temporary landscape. Architectural and Planning Research. 26(2):123-135.

Miles S (2014). Youth Sociology. Qharib M, Javan N, translators. Tehran: Sociologists. [Persian]

Ghalambar Dezfoli M, Naghizade M (2014). Urban space design to promote social interactions (Case study: Interdistrict Blvd). Hoviatshahr. 17(6):15-24. [Persian]

Mohammadi B, Sharepour M (2018). Investigation of the youth's social relationships and their interactions in park (Case study: Amol city). Social Development. 12(4):131166. [Persian]

Qhanbaran A, Jafari M (2015). Investigating the factors affecting the promotion of social interactions among residents of the residential neighborhood (Case study: Dereh-e-Tehran). Iranian Architecture and Urbanism. 5(7):57-64. [Persian]

Rogers P (2006). Young People's participation in the renaissance of public space- a case study in Newcastle

\section{نتيجه گيرى}

تمايل به مشاركت، حق انتخاب، آزادى عمل، حضور در فضاهاى

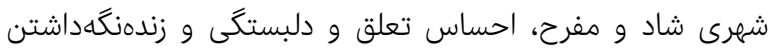
آيينهاى بومى به عنوان نيازهاى جوانان در برقرارى تعاملات اجتماعى در بستر مناظر موقت شهر تشخيص به داده شد.

$$
\begin{aligned}
& \text { تشكر و قدردانى: موردى از سوى نويسندگًان گَزارش نشده است. }
\end{aligned}
$$

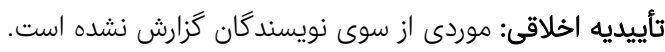

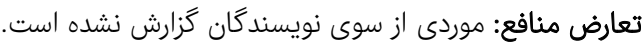

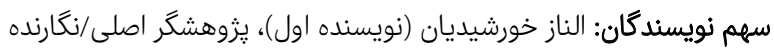
بحث (هڤ\%)؛ فاطمه محمدنياى قرائى (نويسنده دوم)، تحليلكر بحث

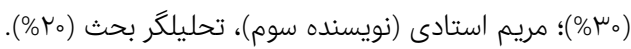

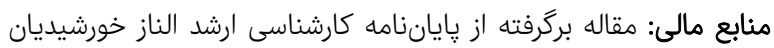
در دانشگاه آزاد اسلامى واحد مشهيد است.

\section{منابع}

Hang S (2007). A temporary landscape recipe-to reclaim Hong Kong's lost landscape opportunity [Dissertation]. Hong Kong: University of Hong Kong.

Askari Nadoushan A, Sabaghchi M (2018). The Use of Importance-Performance Analysis (IPA) in evaluating gap between youth needs and policies' proprieties in Yazd, Iran. Applied Sociology. 29(2):39-64. [Persian] 
temporary landscapes in order to improve the quality of the urban living environment. Urban Management Studies. 5(3):27-38. [Persian]

Tusi Sadr M (2013). The life of young people in the city. Tehran: Tissar. [Persian]

White R (1998). Public space for young people: A guide to creative projects and positive strategies. Australia: Australian Youth Foundation, East Sydney.
Upon Tyne, UK. Children, Youth and Environments. 16(2):105-126.

Shojaei D, Partoee P (2015). Analysis of factors affecting the creation and promotion of sociability in public spaces in different scales of Tehran city (Case studies: Two neighborhoods and an area in district 7 Tehran). Bagh-E Nazar. 12(34):93-108. [Persian]

Siami Gh, Harivandi N, Kangi T (2013). Locating the 